\title{
Evaluation of the Biochemical Stress Response to Chlorpyrifos in Tissues of the Edible Crab Barytelphusa guerini: Withdrawal of Exposure Improves the Nutritional Value
}

\author{
Madhusudan Reddy Narra ${ }^{\mathrm{a}}$, Kodimyala Rajender ${ }^{\mathrm{a}}$, J. Venkateswara Rao ${ }^{\mathrm{b}}$, \\ and Ghousia Begum ${ }^{\mathrm{b}, *}$ \\ a Department of Zoology, College of Science, Osmania University, \\ Hyderabad 500 007, A. P., India \\ b Toxicology Unit, Biology Division, Indian Institute of Chemical Technology, \\ Hyderabad 500 007, A. P., India. Fax: +91 (40) 27193227. \\ E-mail: ghousia@iict.res.in or ghousia786@yahoo.com \\ * Author for correspondence and reprint requests \\ Z. Naturforsch. 68c, 318-326 (2013); received April 20, 2012/May 28, 2013
}

The sublethal stress of the organophosphate insecticide chlorpyrifos was investigated in different tissues of the freshwater crab (Barytelphusa guerini). Crabs were exposed to $1 / 3$ of $\mathrm{LC}_{50}$ concentrations for 7, 14, 21, and 28 days. After 28 days, they were released into fresh water and kept for 18 days for recovery. The study was conducted by estimating total proteins, amino acids, ammonia, urea, and glutamine levels, and protease, transaminases, and phosphatases activities. Total proteins level was decreased whereas amino acids and ammonia were increased. The urea content was decreased in all tissues and glutamine exhibited a mixed response. Protease activities and those of alanine and aspartate aminotransferase, respectively, were elevated. Acid phosphatase activity was reduced in hepatopancreas and brain and induced in gills and muscle. Alkaline phosphatase activity was enhanced in gills and hepatopancreas and reduced in muscle and brain. The crabs recovered from the biochemical stress caused by chlorpyrifos after their release into fresh water.

Key words: Chlorpyrifos, Nutritional Value, Edible Crab

\section{Introduction}

It has been reported that as much as $70 \%$ of the pesticides used in pest control programs in agriculture affect non-target organisms inhabiting rivers, estuaries, and adjacent aquaculture ponds that are fed by the rivers/estuaries (Ozha, 1998; Selvakumar et al., 2005). Organophosphate pesticides are an important insecticide class, which are widely used in agriculture and for domestic purposes to control insect pests (Rodrigues et al., 2001). Crab fishery is developing rapidly, and there is a vast potential market for crab meat due to its delicacy and nutritional richness. Some species of crabs are edible and a number of others are commercially important for the fishmeal industry. Among the various resources, crab is a valuable and easily accessible food, rich in lipids. A crab contains lipids of superior nutritional quality; it represents an important category of seafood. The nutritional value of crabs depends on their biochemical components such as proteins, carbohydrates, and lipids. These components serve as sen- sitive indicators for detecting potential adverse effects, particularly the early events of pollutant damage, because their alterations appear before the clinical symptoms produced by the toxicant (Almeida et al., 2002; Rao, 2006).

The organophosphate insecticides are known to affect crustaceans; e.g. monocrotophos interferes with the neuroendocrine regulation in the freshwater crab Barytelphusa guerini (Patil et al., 2008), chlorpyrifos affects survival and growth of Palaemonetes argentines (Montagna and Collins, 2007), the nutritive value of the freshwater fieldcrab Spiralothelphusa hydrodroma (Senthilkumar et al., 2007), as well as oxygen consumption and ammonia excretion of the freshwater crab Trichodactylus borellianus (Montagna and Collins, 2008). In this context, it is noteworthy to mention that information on recovery of crabs after cessation of toxic exposure is lacking. Therefore, the present study was undertaken to investigate the effect of a sublethal concentration of chlorpyrifos on metabolites (total proteins, 
amino acids, ammonia, urea, and glutamine) and enzymes (transaminases and phosphatases) of the protein metabolism in metabolically active tissues (gills, muscle, hepatopancreas, and brain) of the freshwater crab Barytelphusa guerini. This crab is cultured as paddy cum crab and is of high nutritional importance for rural populations. Chlorpyrifos $[O, O$-diethyl- $O$-(3,5,6-trichloro-2-pyridyl) phosphorothioate, $\mathrm{CPF}$ ] is a broad-spectrum insecticide commonly known as dursban. It is used extensively for the management of domestic and agricultural pests. It is effective in controlling Coleoptera, Diptera, Homoptera, and Lepidoptera in soil or on foliage of over 100 crops. The study was conducted for a total of 28 days, and samples were taken after 7, 14, 21, and 28 days. Crabs exposed to chlorpyrifos for four weeks were released into freshwater in order to follow readjustment of metabolism once the toxic agent is withdrawn. The recovery study was carried out at intervals of 3 days up to 18 days.

\section{Material and Methods}

The freshwater crabs Barytelphusa guerini (H. Milne Edwards) were collected from a local supplier and brought to the laboratory in aerated large plastic tubs. They were acclimatized for $30 \mathrm{~d}$ in a large cement tank, submerged under water, and fed with commercially available dry prawns. Crabs weighing between 40 and $45 \mathrm{~g}$ were transferred to plastic tubs for a further period of four weeks for conditioning. The natural photoperiod of $12 \mathrm{~h}$ light $/ 12 \mathrm{~h}$ dark was maintained. The average values of water quality during the investigation were as follows: temperature, $(25 \pm 3)$ ${ }^{\circ} \mathrm{C} ; \mathrm{pH}, 7.4 \pm 0.4$; dissolved oxygen, $(8.24 \pm 0.22)$ $\mathrm{mg} / \mathrm{L}$; total hardness, $(415 \pm 1.2) \mathrm{mg} / \mathrm{L}$ as $\mathrm{CaCO}_{3}$; alkalinity, $(348 \pm 1.6) \mathrm{mg} / \mathrm{L}$ as $\mathrm{CaCO}_{3}$; and chloride, $(245.57 \pm 1.44) \mathrm{mg} / \mathrm{L}$.

The insecticide chlorpyrifos (20\% EC) was purchased from a local market (National Organic Chemical Industry Limited, Bombay, India). The 96-h LC $_{50}$ value of CPF was determined in the laboratory using the semi-static method of Finney (1971). A stock solution of CPF was prepared by dissolving it in acetone. A control group of 24 crabs was kept in water with addition of the carrier solvent acetone. During subacute studies, a group of 60 crabs were exposed to sublethal concentrations of $0.07 \mathrm{ppm}$ chlorpyrifos (1/3 of $96-\mathrm{h}$ $\mathrm{LC}_{50}$ of $0.21 \mathrm{ppm}$ ) for a period of $28 \mathrm{~d}$. After four weeks, 36 crabs were released into freshwater and kept there for $18 \mathrm{~d}$ in order to study the recovery pattern. Water was renewed daily and the required concentration was maintained by adding the toxicant directly to the water. Crabs were starved $24 \mathrm{~h}$ prior to sampling. At intervals of $7 \mathrm{~d}$, sampling of control and exposed crabs was done (up to $28 \mathrm{~d}$ ); sampling during recovery was done at intervals of $3 \mathrm{~d}$ for a period of $18 \mathrm{~d}$. Crabs were sacrificed, and gills, leg muscle (hereafter called muscle), hepatopancreas, and nervous tissue (brain) were dissected carefully and used for the determination of biochemical parameters.

Homogenates $(1 \%, w / v)$ of the tissues were prepared in trichloroacetic acid (TCA) using a Potter-Elvehjem homogenizer for the estimation of total proteins (Lowry et al., 1951) using bovine serum albumin as standard. Free amino acids (FAA) were assayed by the method of Moore and Stein (1954) using tyrosine as standard. Levels of ammonia were determined using ammonium chloride as standard (Natelson, 1971), of urea by the diacetyl monoxime method (Natelson, 1971), and of glutamine by the acid hydrolysis method of Wilcox (1967).

For the assays of aspartate aminotransferase (AAT) (E.C.2.6.1.1) and alanine aminotransferase (ALAT) (E.C.2.6.1.2), 5\% (w/v) homogenates of tissues were prepared in $0.25 \mathrm{M}$ ice-cold sucrose solution, and the activities determined by the method of Reitman and Frankel (1957). Protease activity was measured as described by Moore and Stein (1954); the reaction mixture contained $100 \mu \mathrm{L}$ of sodium phosphate buffer $(100 \mu \mathrm{M}, \mathrm{pH}$ 7.0) and $12 \mathrm{mg}$ of denatured (heated at $41^{\circ} \mathrm{C}$ ) hemoglobin as substrate. The activity of protease is represented as $\mathrm{mg}$ amino acids released/ ( $\mathrm{g}$ protein $\mathrm{h}$ ). Activities of alkaline phosphatase (ALP) (E.C.3.13.1) and acid phosphatase (ACP) (E.C.3.13.2) were determined by the methods of Moss et al. (1986) and Jabeen (1984), respectively.

The experiments were repeated three times, and data were analysed by Student's $t$-test. There was no significant change in the values of controls, so summarized control values were used. Significant differences from exposure values above 5\% were accepted as levels of statistical significance.

\section{Results}

Freshwater crabs, Barytelphusa guerini, were exposed to a sublethal concentration of chlor- 
pyrifos for 28 days. Their recovery was assessed after transfer into freshwater and further maintenance for 18 days. Biochemical parameters were determined both during the exposure and recovery phase in regular intervals. The results are presented in Figs. 1 to 5. The total proteins content decreased continuously in gill, muscle, hepatopancreas, and brain during the exposure period (Fig. 1A). The maximum decrease was noticed in the brain. After cessation of toxicant exposure, all values exhibited a recovery response. Increases in free amino acids and ammonia levels were observed in all tissues (Figs. 1B, 2A). The increases were continuous throughout the 28 days. The highest increase in ammonia content was shown by gill and brain, respectively. There was more recovery in the ammonia than in the amino acids content, respectively, during the recovery period. The urea content decreased in all tissues, maximum decrease was observed in hepatopancreas followed by muscle, gill, and brain. After cessation of CPF toxicity, the muscle urea content returned to control levels, whereas gill, hepatopancreas, and brain showed more recovery (Fig. 2B). Gill and hepatopancreas glutamine contents increased throughout the exposure period, while they decreased in muscle and brain. When the CPF preexposed crabs were transferred into clean water, the glutamine level recovered to the control value in gill; recovery was also more in hepatopancreas and the difference between control and recovered hepatopancreas tissue was $-2 \%$ (significant) (Fig. 3A). Of all the metabolites investigated, recovery in the urea content was highest, followed by the ammonia content.

Protease activity increased continuously during the exposure period (Fig. 3B). Maximum induction was shown by hepatopancreas followed by gill, brain, and muscle. Slight to more recovery in the activity of protease was noted. Aspartate
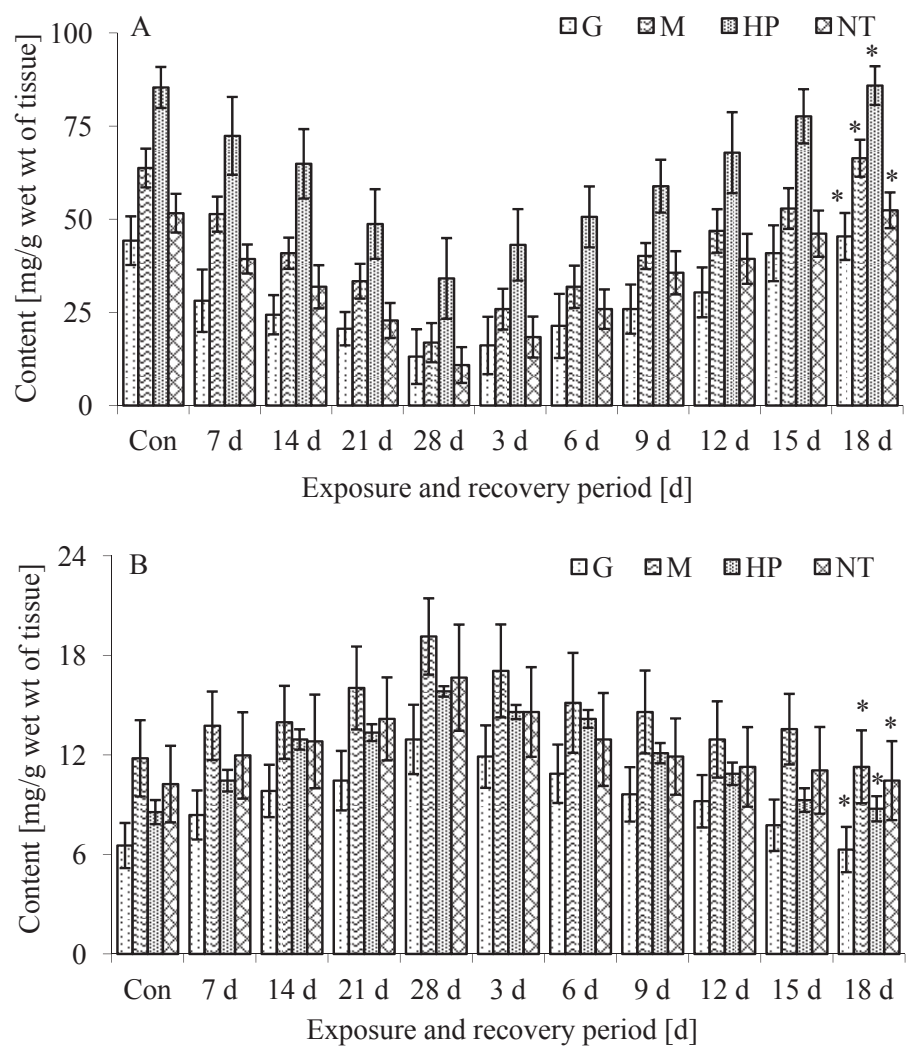

Fig. 1. Contents of (A) total proteins and (B) free amino acids in tissues of Barytelphusa guerini exposed to sublethal concentrations of chlorpyrifos for 28 days followed by 18 days of recovery. The experiment was repeated three times. Con, control; G, gills; M, muscle; HP, hepatopancreas; NT, nervous tissue. * $P>0.05$. 

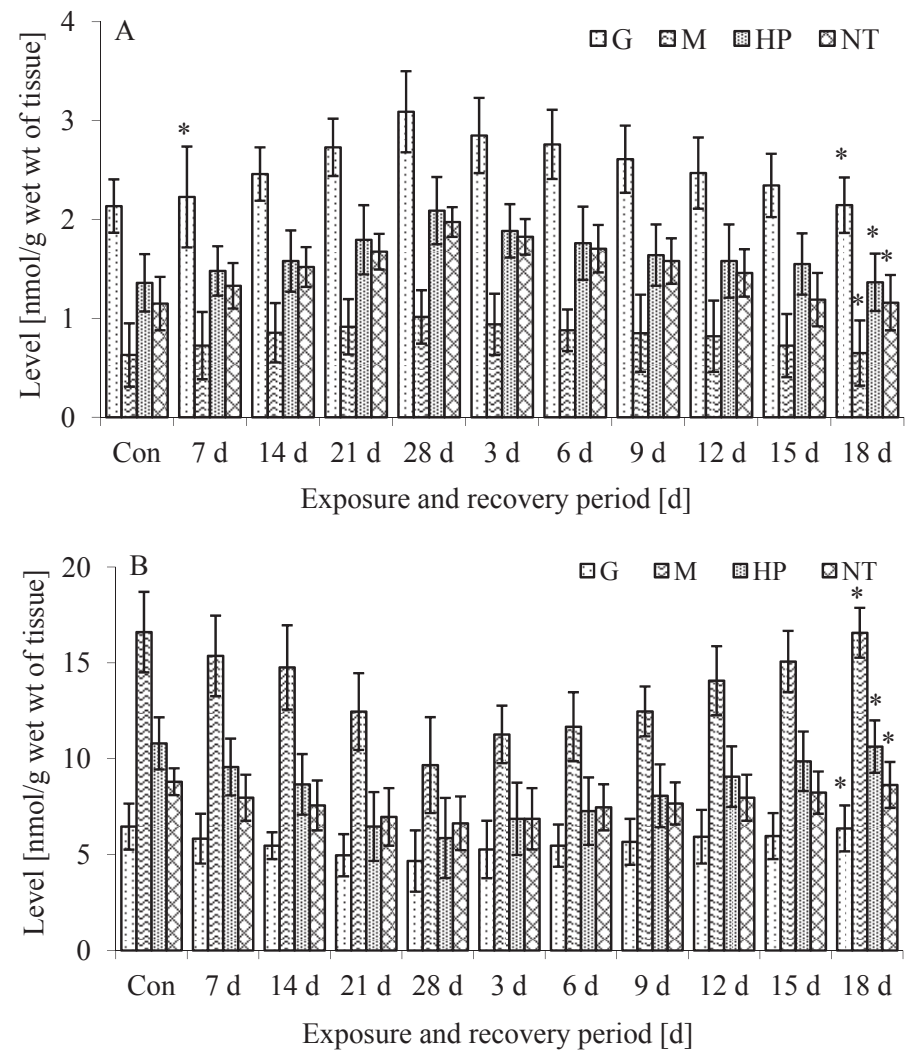

Fig. 2. Levels of (A) ammonia and (B) urea in different tissues of Barytelphusa guerini. See legend to Fig. 1 for conditions.

and alanine transaminase activities were induced in gill, muscle, hepatopancreas, and brain during 4 weeks of CPF intoxication, and there was recovery when the crabs were released into freshwater (Figs. 4A, 4B). Recovery in the alinine activity was almost near to the control in muscle and brain, the difference between the control and recovered groups was 1.5 and $1.9 \%$ (significant), respectively (Fig. 4B).

The reduction in acid phosphatase activity was gradual in hepatopancreas and brain, being highest $(-55 \%$ and $-44 \%)$ at the end of 4 weeks, while gill and muscle acid phosphatase activities were enhanced. When CPF-exposed crabs were kept in clean water for 18 days, the acid phosphatase activity recovered and maximum recovery was seen in gills (Fig. 5A). The alkaline phosphatase activity was enhanced in gill and hepatopancreas and reduced in muscle and brain (Fig. 5B). When the crabs were released into freshwater, the alkaline phosphatase activity recovered in all tissues.

\section{Discussion}

The freshwater crustacean Barytelphusa guerini is a nutritious food source for humans. The nutritive value depends on constituents such as proteins, carbohydrates, and lipids. Under extreme stress conditions, proteins supply energy in metabolic pathways and biochemical reactions. Therefore, an assessment of the protein content in different tissues can be used as a diagnostic tool for determining the physiological state of an organism (Prasath and Arivoli, 2008). The decrease in the protein content in tissues of B. guerini within 28 days suggests active proteolysis. Pesticides are known to induce depletion of the protein content of B. guerini exposed to endosulfan (Reddy et al., 1991) and in Spiralothelphusa hydrodroma exposed to cypermethrin (Sreenivasan et al., 2009). Senthilkumar et al. (2007) also reported a decreased protein content in different tissues of the field crab Spiralothelphusa hydrodroma exposed 

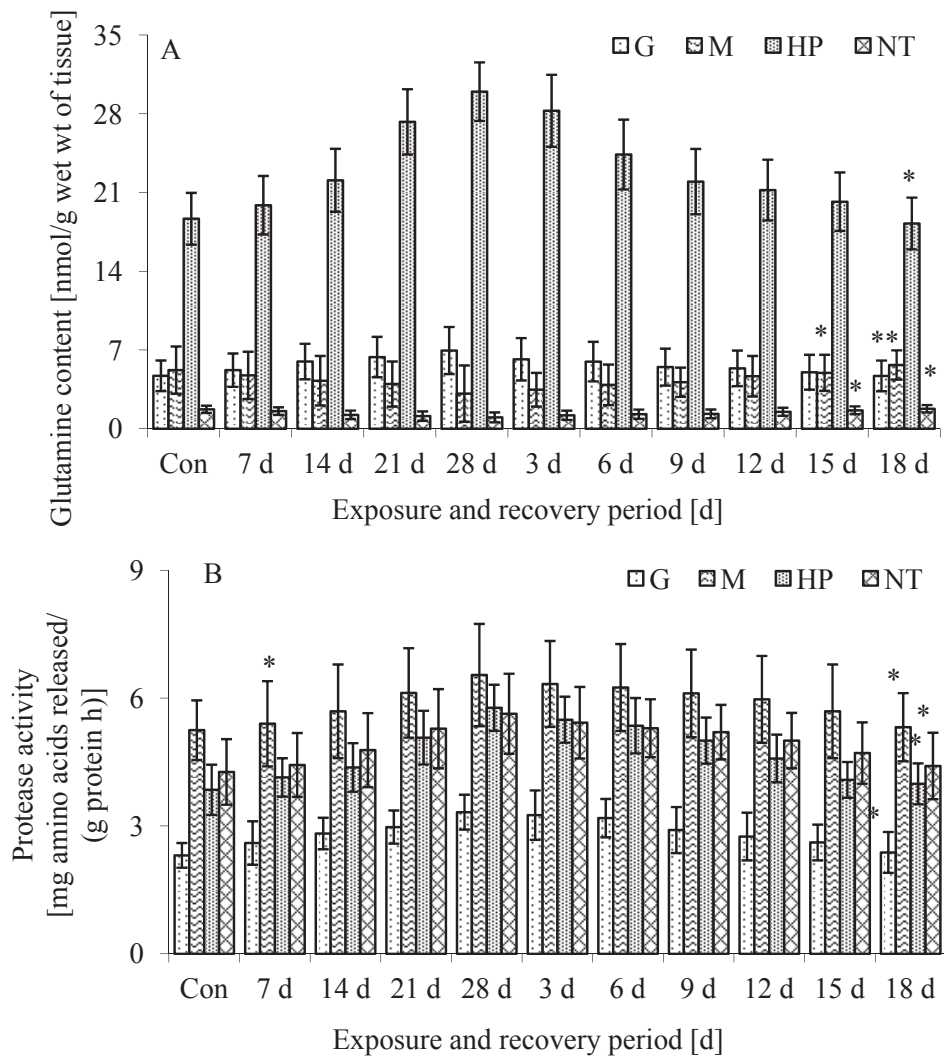

Fig. 3. (A) Glutamine content and (B) protease activity in tissues of Barytelphusa guerini. See legend to Fig. 1 for conditions.

to lower and higher concentration of chlorpyrifos. Protein depletion in tissues constitutes a physiological mechanism which provides energy to cope with the stress of $\mathrm{CPF}$ intoxication. The reduction could also be due to the direct effect of CPF on protein metabolic demand as suggested by Senthilkumar et al. (2007). The quantity of protein is dependent on the rates of protein synthesis and degradation (Ogueji and Auta, 2007). A decrease in DNA and RNA contents in tissues of Scylla serrata exposed to napththalene has been reported by Vijayavel and Balasubramanian (2006). The depletion in total proteins in the present study might be due to the inhibition of RNA synthesis at the transcriptional level (Singh et al., 1996). The decrease in the protein content could also be due to the production of heat-shock proteins or destructive free radicals as a result of pesticide-induced apoptosis as suggested by Selvakumar et al. (2005). There are no reports in the literature on the recovery of crustaceans from the impact of toxicants. In the present study, when crabs exposed to CPF for four weeks were released into freshwater, recovery of the total proteins content was observed. Alterations in the amino acids level indicate the condition of a tissue, and its increase or decrease might be considered as the operation of the stress phenomenon at the tissue level (Shakoori et al., 1976). Increased levels of free amino acids observed in the present study might be due to their decreased utilization and are also suggestive of the protein catabolism. When B. guerini were transferred to clean water, the recovery of the free amino acids content indicates that these tissues had actually recovered from CPF toxicity. At the end of 18 days of recovery, slight decreases $(4 \%)$ in the amino acids levels were observed in gill and muscle tissue.

Ammonia, amino acids, and urea are the three principal end products of the protein catabolism that are released into the environment through gills in decapods (Regnault, 1987). The elevated ammonia content might be due to increased am- 

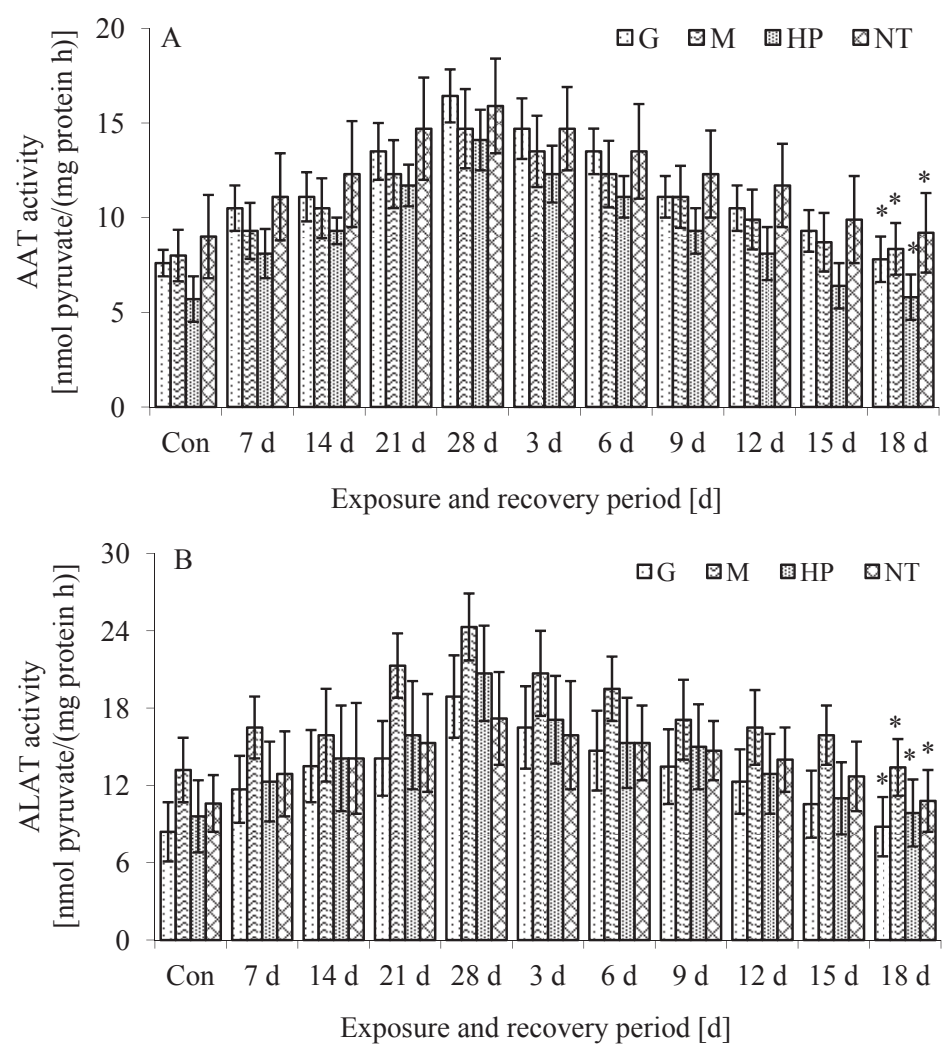

Fig. 4. Activities of (A) aspartate aminotransferase and (B) alanine aminotransferase in tissues of Barytelphusa guerini. See legend to Fig. 1 for conditions.

moniagenesis in CPF-intoxicated crabs. Ammonia is a toxic metabolite, and excess ammonia is known to trigger the operation of detoxification or utilization systems, chiefly by way of formation of less toxic nitrogenous substances such as urea and glutamine (Begum, 2004). The decrease in the urea content suggests its elimination from the body. After cessation of toxicity, recovery in ammonia and urea contents was observed. Mobilization of ammonia towards the formation of the less toxic compound glutamine is also evident from this study. According to Philip and Rajasree (1996), glutamine production will be switched on when the tissue accumulates ammonia. Synthesizing glutamine from toxic ammonia might have helped the crab to overcome the stress of CPF intoxication. The decrease in the glutamine levels in muscle and nervous tissue was a tissue-specific response. At the end of 18 days of recovery, the glutamine level in gill tissue was near to the control value. The activity of protease was induced in all tissues, highest induction was observed in hepatopancreas. Increased proteolysis as a result of enhanced protease activity provides more energy to compensate the stress caused by the toxicity of CPF. After 18 days in clean water, recovery in protease activity was observed.

Marker enzymes, such as phosphatases and transaminases, serve as specific indicators of water pollution-induced changes in enzyme activities of crustaceans (Vijayavel and Balasubramanian, 2006). The acid phosphatase activity was reduced in hepatopancreas and nervous tissue (Fig. 5A), which could be due to the direct inhibitory action of CPF on acid phosphatase. A similar reduction in acid phosphatase activity in tissues of prawns exposed to endosulfan was reported by Bhavan and Geraldine (2001). In the present study, the acid phosphatase activity was increased in gill and muscle tissue. The increase could be due to the destruction of the lysosomal membrane, thus causing the release of enzyme. Acid phosphatase induction reflects proliferation of lysosomes in an attempt to sequester the toxic xenobiotic (Gill 

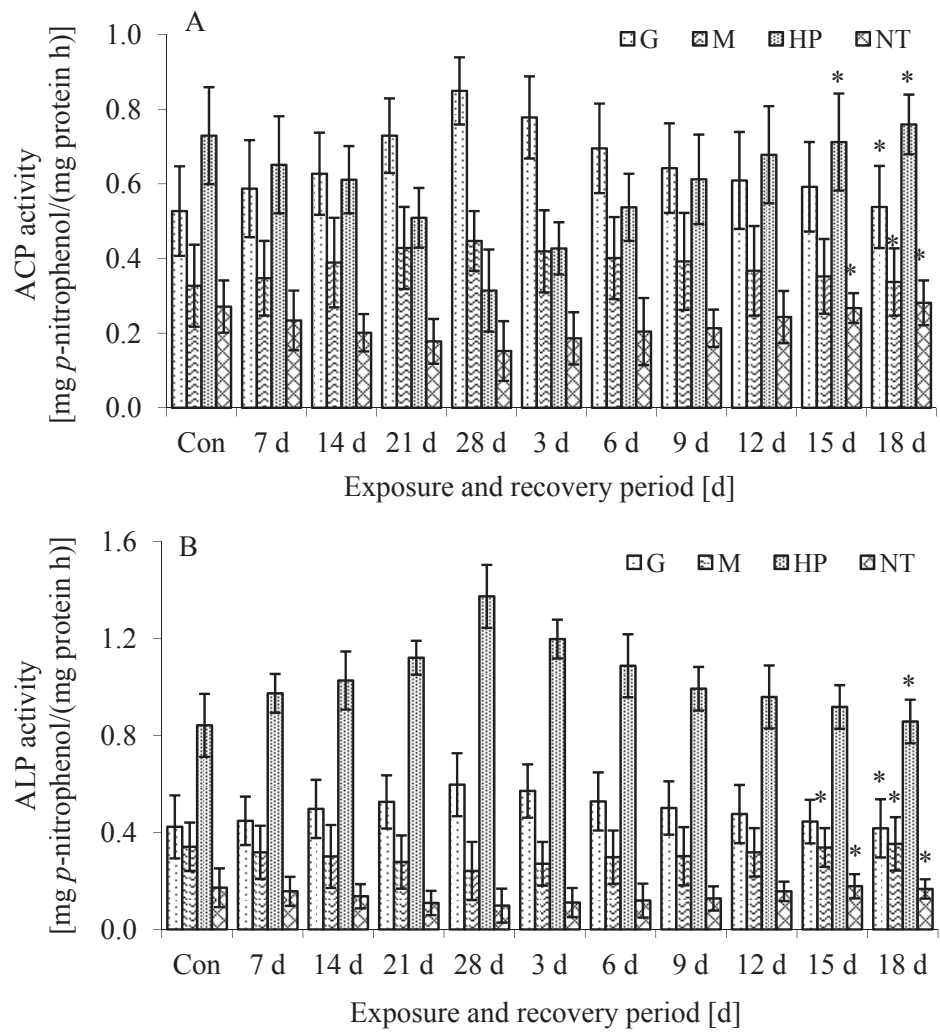

Fig. 5. Activities of (A) acid phosphatase and (B) alkaline phosphatase in tissues of Barytelphusa guerini. See legend to Fig. 1 for conditions.

et al., 1992). Acid phosphatase in gill tissue recovered maximally after transfer of the crabs from CPF toxicant to freshwater. CPF-caused induction in the alkaline phosphatase activity in gill and hepatopancreas might be due to the accelerated membrane transport function related to anion-hydroxide exchange across the lipid biomembranes mediated by organotin compounds as suggested by Jaroli and Sharma (2005). Another reason for the increase could be the destruction of smooth endoplasmic reticulum membrane (Khan and Pandya, 1986). Reduction in the alkaline phosphatase activity in nervous tissue and leg muscle can be taken as an index of parenchymal damage, necrosis, and uncoupling of oxidative phosphorylation. When the crabs were transferred into CPF-free water, the alkaline phosphatase activity recovered maximally in gill tissue.

Enhanced transaminase activities may feed amino acids into the TCA cycle in order to cope with the enhanced energy requirement under the toxic stress of CPF. Similar increases in aspartate aminotransferase and alanine aminotransferase activities were reported in tissues of crabs exposed to organophosphate pesticides (Reddy et al., 1987). The elevation in transaminase activity might be due to the decreased protein content observed in the tissues of the crab. When CPF-exposed crabs were released into freshwater, recovery in aspartate aminotransferase and alanine aminotransferase was highest in hepatopancreas and leg muscle. The difference between the control and the recovered leg muscle was only $1.5 \%$. The recovery might be due to increased rates of enzyme synthesis in order to compensate for the activity of lost enzyme as suggested by Ay et al. (1999).

\section{Conclusion}

The present study demonstrates the sublethal effect of CPF on the protein metabolism of the crab Barytelphusa guerini. CPF caused altera- 
tions in the crab physiology which affect both metabolites and enzymes. Some tissue-specific responses were observed in crabs under the impact of CPF. Transfer of the crabs into freshwater largely normalized the protein metabolism, this in turn reflects on the nutritional value of crab. From the results it is clear that a recovery pe-

Almeida J. A., Diniz Y. S., Marques S. F. G., Faine I. A., Ribas B. O., Burneiko R. C., and Novelli E. I. B. (2002), The use of the oxidative stress responses as biomarkers in Nile tilapia (Oreochromis niloticus) exposed to in vivo cadmium contamination. Environ. Toxicol. 16, 673-679.

Ay O., Kalay M., Tamer L., and Canli M. (1999), Copper and lead accumulation in tissues of freshwater fish Tilapia zilla and its effects on the branchial $\mathrm{Na}^{+}, \mathrm{K}^{+}$ ATPase activity. Bull. Environ. Contam. Toxicol. 5, $160-168$.

Begum G. (2004), Carbofuran insecticide induced biochemical alterations in liver and muscle tissues of the fish Clarias batrachus (Linn.) and recovery response. Aquat. Toxicol. 55, 83-92.

Bhavan P. S. and Geraldine P. (2001), Biochemical stress responses in tissues of the prawn Macrobrachium malcolmsonii on exposure to endosulfan. Pest. Biochem. Physiol. 70, 27-41.

Finney D. J. (1971), Probit Analysis, 2nd ed. Cambridge University Press, Cambridge, London, UK.

Gill T., Tewari H., and Pande J. (1992), Short and longterm effects of copper on the rosy carb (Puntius conchonius). Ecotoxicol. Environ. Safety 23, 294-297.

Jabeen K. (1984), Toxicological evaluation of some pesticides against chicken (Gallus gallus domesticus) and rat (Rattus rattus norvegicus) with special reference to haematology, blood and urine biochemistry. $\mathrm{PhD}$ thesis. Osmania University, Hyderabad, India.

Jaroli D. P. and Sharma B. L. (2005), Effect of organophosphate insecticide on the organic constituents in liver of Channa punctatus. Asian J. Exp. Sci. 19, $121-129$.

Khan S. and Pandya K. P. (1986), Hepatoxicity in albino rats exposed to $n$-octane and $n$-nonane. J. Appl. Toxicol. 5, 64-68.

Lowry O. H., Rosebrough N. J., Farr A. L., and Randall R. J. (1951), Protein measurement with Folin phenol reagent. J. Biol. Chem. 193, 265-275.

Montagna M. C. and Collins P. A. (2007), Survival and growth of Palaemonetes argentinus (Decapods; Caridae) exposed to insecticides with chlorpyrifos and endosulfan as active element. Arch. Environ. Contam. Toxicol. 53, 371-378.

Montagna M. C. and Collins P. A. (2008), Oxygen consumption and ammonia excretion of the freshwater crab Trichodactylus borellianus exposed to chlorpyrifos and endosulfan insecticides. Pest. Biochem. Physiol. 92, 150-155. riod of 18 days is not sufficient; a longer recovery period would be necessary in order to bring the crab metabolism back to normal. However, more investigations are needed to understand the exact compensatory role of the protein metabolism and also to allow the crabs to recover completely.

Moore S. and Stein W. H. (1954), A modified ninhydrin reagent for the photometric determination of amino acids and related compounds. J. Biol. Chem. 221, 907-913.

Moss D. W., Henderson A. R., and Kochmar J. F. (1986), In: Enzymes Principles of Diagnostic Enzymology and the Aminotransferases. Text Book of Clinical Chemistry (Tietz N. W., ed.). Saunders, Philadelphia, PA, USA, pp. 663-768.

Natelson S. (1971), Techniques of Clinical Chemistry, 3rd ed. Charles C. Thomas, Springfield, IL, USA, p. 146.

Ogueji E. O. and Auta J. (2007), Investigations of biochemical effects of acute concentration of lambdacyhalothrin on African catfish Clarias gariepinusTeugels. J. Fish. Int. 2, 86-90.

Ozha D. D. (1998), Water and its formidable pollution: need immediate attention. Res. J. Chem. Environ. 2, 63-65.

Patil C., Paul R., and Malkanna (2008), Neuroendocrine regulation and pesticidal impact on freshwater crab, Barytelphusa guerini (H. Milne Edwards). J. Environ. Biol. 29, 887-892.

Phillip G. H. and Rajasree B. H. (1996), Action of cypermethrin on tissue transamination during nitrogen metabolism in Cyprinus carpio. Ecotoxicol. Environ. Saf. 34, 174-179.

Prasath P. M. D. and Arivoli S. (2008), Biochemical study of freshwater fish Catla catla with reference to mercury chloride. Iran. J. Environ. Health. Sci. Eng. 3, 109-116.

Rao J. V. (2006), Biochemcial alterations in euryhaline fish Oreochromis mossambicus exposed to sub lethal concentration of an organophosphorus insecticide monocrotophos. Chemosphere 65, 1814-1820.

Reddy M. S., Gouselazam S., Babu T. R., and Rao K. V. R. (1987), Changes in respiratory potentials of the penaeid prawn, Metapenaeus monoceros exposed to phosphomidon, DDT and fenvalerate. Environ. Ecol. 4, 643-646.

Reddy A. N., Venugopal N. B. R. K., and Reddy S. L. N. (1991), Effects of endosulfan 35 EC on certain aspects of protein metabolism in various tissues of a fresh water field crab, Barytelphusa guerini. Pest. Biochem. Physiol. 39, 121-129.

Regnault M. (1987), Nitrogen excretion in marine and fresh water crustacean. Biol. Rev. 62, 1-24.

Reitman S. and Frankel S. (1957), A colorimetric method for the determination of serum glutamic oxaloac- 
etate and glutamic pyruvic transaminases. Am. J. Clin. Pathol. 286, 56-63.

Rodrigues E. L., Ranzani-Paiva M. J. T., Pacheco F. J., and Veiga M. L. (2001), Histological lesions in the liver of Prochilodus lineatus (Pisces, Prochilodontidae) exposed to a sublethal concentration of the organophosphate insecticide Dipterex 500 (Trichlorfon). Acta Sci. 23, 503-505.

Selvakumar S., Geraldine P., Shanji S., and Jayakumar T. (2005), Stressor-specific induction of heat shock protein 70 in the freshwater prawn Macrobranchium malcolmsonii (H. Milne Edwards) exposed to the pesticides endosulfan and carbaryl. Pest. Biochem. Physiol. 82, 125-132.

Senthilkumar P., Samyappan K., Jayakumar S., and Deecaraman M. (2007), Effect of chlorpyrifos on the nutritive value in a freshwater fieldcrab, Spiralothelphusa hydrodroma. Res. J. Agric. Biol. Sci. 3, 760-766.

Shakoori A. K., Zaheeer S. A., and Ahmed M. S. (1976), Effect of malathion, dieldrin, and endrin on blood serum protein and free amino acid pool of Channa punctatus (Bloch). Pak. J. Zool. 8, 125-134.

Singh N. N., Das V. K., and Singh S. (1996), Effect of aldrin on carbohydrate, protein, and ionic metabolism of a freshwater catfish, Heteropneustes fossilis. Bull. Environ. Contam. Toxicol. 57, 204-210.

Sreenivasan R. S., Arivalagan M., Vijayananth S., Praveen Kumar P. K., Moorthy P. K., and Deecaraman M. (2009), Effect of cypermethrin, a pyrethroid compound on the nutritive value in a freshwater field crab, Spiralothelphusa hydrodroma (Herbst). Res. J. Agric. Biol. Sci. 5, 572-577.

Vijayavel K. and Balasubramanian M. P. (2006), Fluctuations of biochemical constituents and marker enzymes as a consequence of naphthalene toxicity in the edible estuarine crab Scylla serrata. Ecotoxicol. Environ. Saf. 63, 141-147.

Wilcox P. E. (1967), Determination of amide residues by chemical methods. In: Methods in Enzymology (Hirs C. H. W., ed.). Academic Press, New York, USA, and London, UK, Vol. 11, pp. 63-76. 